\title{
Crude Terpenoid Influence on In Vitro Digestibility of Sagebrush
}

KARL D. STRIBY, CARL L. WAMBOLT, RICK G. KELSEY, AND KRIS M. HAVSTAD

\section{Abstract}

The influence of crude terpenoid content on in vitro organic matter digestibility (IVOMD) was determined for basin big sagebrush (Artemisia tridentata Nutt. ssp. tridentata), Wyoming big sagebrush (A.t. ssp. wyomingensis Beetle and Young), mountain big sagebrush (A.t. ssp. vaseyana [Rydb.] Beetle), and black sagebrush ( $A$. nova Nels.). IVOMD was determined using mule deer (Odocoileus hemionus hemionus), sheep (Ovis ammon aries), and steer (Bos taurus) rumen inocula with current year's growth collected from the 4 taxa at a common site on 1 Jan., 15 Feb., and 1 Apr. 1981. All inocula had similar digestive efficiency. Extracting crude terpenoids from foliage increased IVOMD by an average of $12.3 \%$ overall. Few differences in IVOMD among taxa and dates were evident in foliage after crude terpenoids had been extracted. Order of increasing digestibility among taxa without crude terpenoids extracted was black sagebrush, mountain, Wyoming, and basin big sagebrushes, respectively. IVOMD generally increased from January to April as crude terpenoids decreased. Crude terpenoid concentrations were lowest in mountain big sagebrush, intermediate in black sagebrush and Wyoming big sagebrush, and greatest in basin big sagebrush.

Key words: Artemisia tridentata, Artemista nova, mule deer, terpenoids

The forage utilization of sagebrush (Artemisia) by livestock and big game varies from none to heavy on winter ranges (Hansen and Reid 1975, Carpenter et al. 1979, Peek et al. 1979, Urness 1979, Willms et al. 1979, Krysl et al. 1984). Sagebrush is relatively high in crude protein, phosphorus, and carotene when compared to alternate forage species, especially during the winter (Cook et al. 1954, Hickman 1975, Welch and McArthur 1979a, Welch 1983). However, secondary metabolic products are suspected of influencing sagebrush palatability, digestibility, and intake by browsing animals (Nagy 1979, Welch and McArthur 1981, Welch and Pederson 1981, Kelsey et al. 1983, Personius et al. 1987).

Basin big sagebrush (Artemisia tridentata Nutt. ssp. tridentata), mountain big sagebrush (A.t. ssp. vaseyana [Rydb.] Beetle), Wyoming big sagebrush (A.t. ssp. wyomingensis Beetle and Young), and black sagebrush ( $A$. nova Nels.) are widely distributed on western rangelands. Together they comprise over $70 \%$ of the total sagebrush acreage in the 11 western states (Beetle 1960, Beetle and Young 1965).

The objective was to evaluate the relative winter forage qualities of these 4 sagebrush taxa on the basis of in vitro organic matter digestibility (IVOMD) as it related to crude terpenoid concentrations. We tested the hypothesis that the winter IVOMD of the 4 taxa, growing naturally on a common site, was influenced by the presence of crude terpenoids in their foliage.

\footnotetext{
Authors are former research assistant and associate professor, Animal and Range Sciences Department, Montana State University, Bozeman 59717, research associate professor, Department of Chemistry, University of Montana, Missoula 59812, and associate professor, Animal and Range Sciences Department, Montana State University, Bozeman 59717.

The authors wish to acknowledge the assistance of Dr. Richard Lund with statistica procedures.

This is journal series no. 1871, Montana Agr. Exp. Sta.

Manuscript accepted 3 November 1987
}

Materials and Methods

\section{Study Site}

The study site was at the base of the Absaroka Mountains, $3 \mathrm{~km}$ north of Yellowstone National Park near Gardiner, Mont. The area was composed of several basalt benches with average elevation of $1,950 \mathrm{~m}$. Most slopes had a southwest aspect. Annual precipitation has averaged $400 \mathrm{~mm}$, half of which has been snow (USDA 1981). Thermal springs, glacial drift, and natural erosion have influenced the topography and soils, creating a mosaic of microsites and vegetation. The 4 highly interspersed sagebrush taxa dominated with bluebunch wheatgrass (Agropyron spicatum [Rydb.] Scribn.) and Idaho fescue (Festuca idahoensis Elmer) as subdominants. Local habitat types have been described by Mueggler and Stewart (1980) and McNeal (1984). The study site was part of the northern Yellowstone elk (Cervus elaphus nelsoni) and mule deer (Odocoileus hemionus hemionus) winter range. Moderate to heavy foraging use of sagebrush on the winter range by both elk and deer has been reported (Houston 1982, McNeal 1984).

\section{Sample Collection}

Foliage was collected from each of the 4 sagebrush taxa at the study site on 1 Jan., 15 Feb., and 1 Apr. 1981. Samples were taken from 120 mature plants $(20$ lightly browsed and 20 heavily browsed plants of both mountain and Wyoming big sagebrush and 20 each of light to moderately browsed basin big sagebrush and black sagebrush) available for browsing and of ample size to allow 3 collections. Because light and heavy browse form classes of mountain and Wyoming big sagebrush were easy to distinguish, differences in IVOMD and crude terpenoid concentrations between the form classes were tested. Basin big sagebrush and black sagebrush plants that had been heavily browsed were not common so only plants representing the population majority (light to moderate browsing) were sampled. Ten grams of live, current year leaf and stem growth were clipped from each plant and combined with a like amount from 4 other plants in a plastic bag to provide 4 composite samples of each taxa and the 2 levels of browsing. The composite samples were transported in ice for about 1.5 hours before storing in a freezer at $-.23^{\circ} \mathrm{C}$.

\section{Crude Terpenoid and In Vitro Analysis}

Crude terpenoid compounds in glandular trichomes of leaves (Kelsey and Shafizadeh 1980, Kelsey et al. 1982, Kelsey 1986) were removed and quantified in duplicate from overall composite samples of the 6 taxa-use groups using a rapid extraction with chloroform (Kelsey et al. 1982). After extraction residual chloroform was removed by oven-drying $\left(65^{\circ} \mathrm{C}\right)$ overnight. The samples were then frozen for in vitro digestion.

Sample preparation for determining IVOMD was in a refrigerated room $\left(3^{\circ} \mathrm{C}\right)$ to minimize the escape of volatile compounds. Foliage was super-frozen in liquid nitrogen, then ground using a motorized mortar and pestle (Welch and McArthur 1981, Welch and Pederson 1981). The ground samples were sealed in air-tight plastic bottles and stored in a freezer at $-23^{\circ} \mathrm{C}$. The same procedures were used for samples with crude terpenoids extracted. A total of 90 samples were prepared (24 intact and 6 extracted per date). Dry matter and organic matter were determined in duplicate for each sample. 
Before weighing samples for in vitro digestion, the sample bottles were removed from the freezer and allowed to cquilibrate with the refrigerated room temperature. Weighed aliquots, to the nearest $0.1 \mathrm{mg}$, were adjusted so that $0.5 \mathrm{~g}$ of organic matter was placed in each digestion tube. Tubes were sealed with rubber stoppers fitted with Bunsen valves then returned to the freezer. Thus, samples were not exposed to room temperature until initiation of in vitro digestion. Prior to inoculation, tubes and samples were prewarmed in a water bath to $39^{\circ} \mathrm{C}$.

The Moore modification (Harris 1970) of the Tilley and Terry (1963) in vitro digestion technique was used. Three in vitro digestion trials of each of the 90 samples were conducted with rumen fluid inocula from a wild mule deer, a domestic sheep (Ovis ammon aries), and a steer (Bos taurus). On 18 Apr. 1981, a healthy 2-year old buck mule deer was shot on the study site. The entire rumen and contents were removed and transported in a prewarmed container to a nearby laboratory. Approximately 30 minutes elapsed between removal of the rumen and initiation of the in vitro trial.

A fistulated sheep and steer provided rumen inocula for the other 2 digestion trials conducted during late April, 1981, at the Montana State University Animal Nutrition Center. Both animals were maintained on mixed grass hay (Bromus inermis Leyss and Phleum pratense L.) at least 2 weeks prior to collecting inocula.

A completely random design was employed. The 3 collection dates and 3 animal species were nested within the main-plot factor (taxa with form class) (Snedecor and Cochran 1980). Differences in IVOMD for whole and terpenoid-extracted sagebrush and crude terpenoid concentrations among taxa and collection dates were tested at $\alpha=0.05$. The least significant difference method (Snedecor and Cochran 1980 ) protected by a prior $F$-test, was used for comparing treatment means. There was nonhomogenity of variances among animals, thus the analysis was separated on the basis of animal. A test of IVOMD differences among animal species was not desired as Welch et al. (1983) found little difference in IVOMD among our species. For the analysis of the terpenoidextracted samples, variance component estimates from the duplicate terpenoid-extracted samples and the whole plant samples were used to derive an error mean square for date for each animal (Striby 1985). A paired $t$-test $(\alpha=0.05)$ was used to detect significant differences between IVOMD means of whole and terpenoidextracted samples of common taxon and date classes.

\section{Results}

\section{In Vitro Organic Matter Digestibility}

Analysis of variance showed no significant differences $(P<0.05)$ in IVOMD and crude terpenoid concentrations between light and heavily browsed mountain or Wyoming big sagebrush. Thus, their values were averaged in further data analysis. General trends in IVOMD among sagebrush taxa and collection dates and between whole and terpenoid-extracted sagebrush were the same for all inocula sources (Table 1) as expected (Welch et al. 1983).

The average IVOMD for all taxa and collection dates for the wild mule decr, sheep, and steer inocula sources with whole sagebrush was $50.2 \%, 51.1 \%$, and $51.5 \%$, respectively. With terpenoidextracted sagebrush the average IVOMD was $63.5 \%, 66.0 \%$, and $60.1 \%$, respectively. These differences resulted in an overall increase of $12.3 \%$ after extraction of crude terpenoids. Terpenoidextracted sagebrush that was statistically compared $(P<0.05)$ to whole sagebrush for common taxon and collection dates with each inoculum source had significantly greater IVOMD in all but 1 trial. The mountain big sagebrush in the steer trial was the exception.

Considering all inocula sources and collection dates, the order of decreasing digestibility among whole sagebrush taxa was: basin big sagebrush, Wyoming big sagebrush, mountain big sagebrush, and black sagebrush (Table 1). However, on any particular date, differences among taxa were not always significant $(P<0.05)$. This was most evident for the mule deer inoculum. But, when IVOMD was averaged for each taxon over all dates, all taxa differences for
Table 1. In vitro organic matter digestibility (percentage) of 4 sagebrush taxa (whole and terpenoid-extracted) on 3 dates using wild mule deer, sheep, and steer inoculum.

\begin{tabular}{|c|c|c|c|c|c|c|}
\hline \multirow[b]{2}{*}{ Taxon } & \multicolumn{3}{|c|}{ Whole sagebrush } & \multicolumn{3}{|c|}{$\begin{array}{c}\text { Terpenoid-extracted } \\
\text { sagebrush }\end{array}$} \\
\hline & 1 Jan. & $15 \mathrm{Feb}$ & $1 \mathrm{Apr}$ & 1 Jan. & $15 \mathrm{Feb}$ & $1 \mathrm{Apr}$. \\
\hline $\begin{array}{l}\text { black sagebrush } \\
\text { mountain big sagebrush } \\
\text { Wyoming big sagebrush } \\
\text { basin big sagebrush }\end{array}$ & $\begin{array}{l}37.6^{\mathrm{ael}} \\
45.8^{\mathrm{be}} \\
46.0^{\mathrm{be}} \\
47.2^{\mathrm{be}}\end{array}$ & $\begin{array}{l}45.3^{\text {af }} \\
47.9^{\text {ab }} \\
49.5^{\text {ae }} \\
63.4^{\text {bf }}\end{array}$ & $\begin{array}{l}\quad \mathrm{Mu} \\
46.2^{\mathrm{af}} \\
53.5^{\mathrm{bf}} \\
57.4^{\mathrm{bef}} \\
62.4^{\mathrm{cf}}\end{array}$ & $\begin{array}{l}\text { ule Deer } \\
60.4^{\text {ae }} \\
59.8^{\text {ae }} \\
63.9^{\text {ae }} \\
59.5^{\text {ae }}\end{array}$ & $\begin{array}{l}66.3^{\text {be }} \\
56.4^{\text {ab }} \\
62.9^{\text {abe }} \\
65.6^{\text {be }}\end{array}$ & $\begin{array}{l}65.8^{\text {abe }} \\
58.5^{\text {ab }} \\
67.5^{\text {be }} \\
75.7^{\text {cf }}\end{array}$ \\
\hline $\begin{array}{l}\text { black sagebrush } \\
\text { mountain big sagebrush } \\
\text { Wyoming big sagebrush } \\
\text { basin big sagebrush }\end{array}$ & $\begin{array}{l}41.5^{\text {ne }} \\
45.4^{\text {be }} \\
50.3^{\text {ce }} \\
54.0^{\text {de }}\end{array}$ & $\begin{array}{l}44.7^{\text {af }} \\
48.5^{\text {bf }} \\
52.5^{\text {cf }} \\
55.3^{\text {do }}\end{array}$ & $\begin{array}{l}50.4^{\text {ag }} \\
52.7^{\text {ag }} \\
58.1^{\text {bg }} \\
59.6^{\text {bf }}\end{array}$ & $\begin{array}{l}\text { Sheep } \\
64.9^{\text {be }} \\
57.6^{\text {aft }} \\
69.1^{\text {ce }} \\
71.8^{\text {de }}\end{array}$ & $\begin{array}{l}63.4^{\text {be }} \\
53.8^{\text {ae }} \\
68.6^{\text {ce }} \\
72.3^{\text {def }}\end{array}$ & $\begin{array}{l}64.7^{\text {be }} \\
58.1^{\text {af }} \\
72.3^{\text {ef }} \\
75.2^{\mathrm{df}}\end{array}$ \\
\hline $\begin{array}{l}\text { black sagebrush } \\
\text { mountain big sagebrush } \\
\text { Wyoming big sagebrush } \\
\text { basin big sagebrush }\end{array}$ & $\begin{array}{l}42.4^{\text {ae }} \\
48.3^{\text {be }} \\
50.5^{\text {ce }} \\
55.8^{\text {de }}\end{array}$ & $\begin{array}{l}42.8^{\mathrm{ae}} \\
52.0^{\mathrm{bf}} \\
53.7^{\mathrm{bf}} \\
56.6^{\mathrm{ce}}\end{array}$ & $\begin{array}{l}47.0^{\text {af }} \\
53.0^{\text {bf }} \\
57.8^{\text {cz }} \\
58.4^{\text {ee }}\end{array}$ & $\begin{array}{l}\text { Steer } \\
56.2^{\text {be }} \\
46.7^{\text {ar }} \\
69.3^{\text {ce }} \\
68.7^{\infty}\end{array}$ & $\begin{array}{l}53.9^{\text {be }} \\
43.7^{\text {ae }} \\
68.4^{\text {ce }} \\
69.1^{\text {ce }}\end{array}$ & $\begin{array}{l}55.3^{\text {be }} \\
47.4^{\text {af }} \\
70.3^{\text {ce }} \\
72.3^{\text {ce }}\end{array}$ \\
\hline
\end{tabular}

${ }^{1}$ Means among taxa differ $(P<0.05)$ within date and inoculum source when followed by a different letter $(a, b, c, d)$. Means among dates differ $(P<0.05)$ within taxon and inoculum source when followed by a different letter $(e, f, g)$. Comparisons do not apply across whole and terpenoid-extracted data.

whole sagebrush were significant $(P<0.05)$ except between mountain and Wyoming big sagebrush for mule deer inoculum.

Order of increasing IVOMD among terpenoid-extracted sagebrush taxa differed from whole sagebrush (Table 1). Generally, there were fewer significant differences $(P<0.05)$ among taxa for all inocula sources. With IVOMD for terpenoid-extracted material averaged over the 3 collection dates, mountain big sagebrush had significantly lower IVOMD than the other taxa for each inoculum source.

For whole sagebrush taxa there were consistent increases in IVOMD over collection dates in all trials (Table 1). However, successive increases were not always significant. In all but 1 trial, basin big sagebrush-steer inoculum (Table 1), IVOMD on 1 April was significantly greater than on 1 January. When IVOMD's were averaged by collection date, there were significant $(P<0.05)$ increases in digestibility from 1 January to 15 February to 1 April for all 3 inocula sources.

For terpenoid-extracted sagebrush taxa, trends in IVOMD over collection dates were inconsistent (Table 1). For a given taxon there were few significant changes in digestibility over time for all inocula sources. This resulted from removing the influence of changing crude terpenoid levels over time.

\section{Crude Terpenoid Concentration}

Differences $(P<0.05)$ in crude terpenoid concentrations (Fig. 1) averaged over all 3 dates found mountain big sagebrush with the least, black sagebrush and Wyoming big sagebrush with intermediate levels, and basin big sagebrush with the most. For individual taxa, crude terpenoid concentration generally decreased over time. When taxa concentrations were averaged for each collection date, the concentration on 1 April was less $(P<0.05)$ than the concentrations on 15 February and 1 January, which were similar.

Within each taxon, there was a general negative relationship between crude terpenoid concentration and digestibility over the 3 sampling dates. However, this relationship did not exist among taxa. Basin big sagebrush had the highest crude terpenoid concentration but also had the highest digestibility in all trials. Mountain big sagebrush, which had the lowest crude terpenoid concentration was intermediate in digestibility between black sagebrush and Wyoming big sagebrush. 


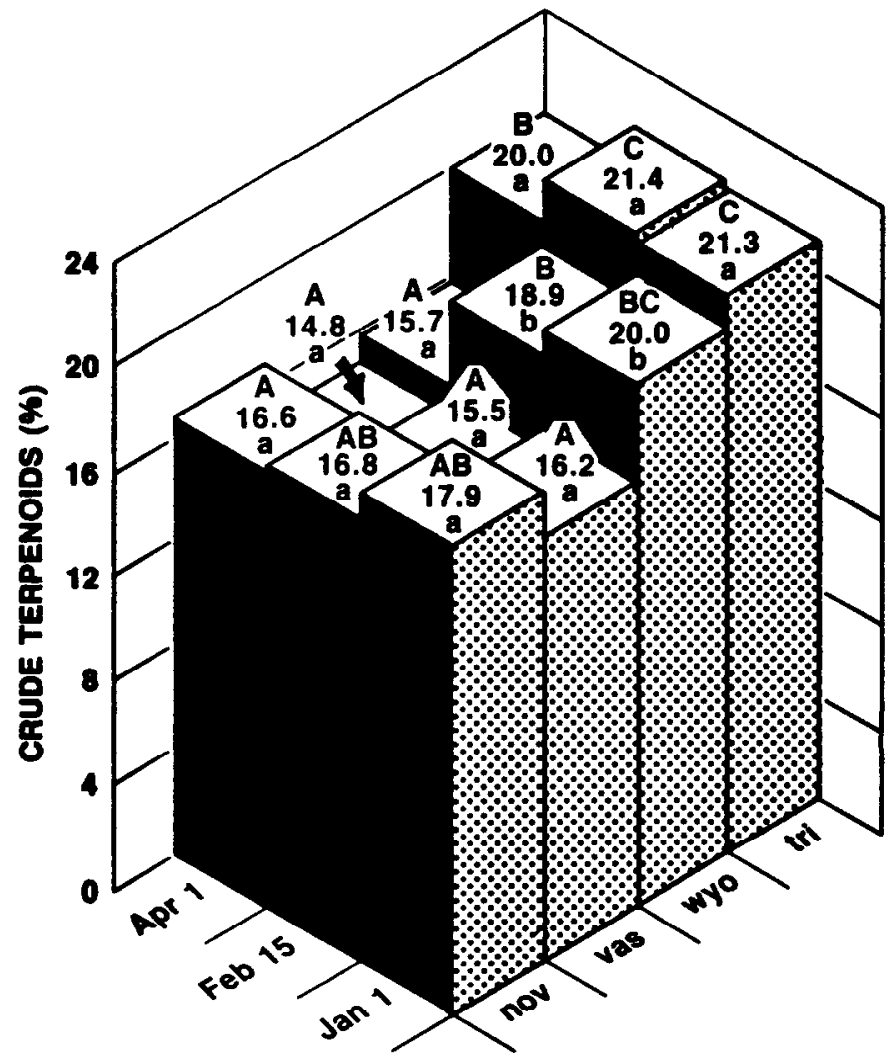

Fig. 1. Percent dry weight crude terpenoid concentrations (percent foliage dry weight) of 4 sagebrush taxa on 3 dates. Taxa: nov = black sagebrush; vas, wyo, tri = mountain, Wyoming, and basin big sagebrush, respectively. Values among taxa on a given date with unlike capital letters are significantly different $(\mathrm{P}<0.05)$. Values among dates for a given taxon with unlike lower case letters are significantly different $(\mathrm{P}<0.05)$.

\section{Discussion}

There are 2 possible explanations for the increase in IVOMD after extraction of crude terpenoids. The crude terpenoid compounds might independently or synergistically play an active role in microbial inhibition, or the crude terpenoids may play a passive role by merely being inert substances that are impervious to microbial digestion.

The highly volatile epidermal compounds of sagebrush foliage include monoterpenes and nonterpenoid organics such as methacrolein, acetone, and ethanol. Most of these are lost during the isolation and concentration of the crude terpenoid extract (Personius et al. 1987). The less volatile compounds are monoterpenes of lower volatility, a portion of which makes up the final concentrated crude terpenoid extract. These monoterpenes can be separated from the nonyolatile components in the extract by steam distillation. The nonvolatile fraction of epidermal foliage contains sesquiterpene lactones, cuticular waxes, some phenolics, and possibly other miscellaneous compounds (Kelsey et al. 1982, Personius et al. 1987). These differences in volatility are important when considering the influence that these substances might have on IVOMD.

Welch and Pederson (1981) demonstrated that oven-drying sagebrush at $100^{\circ} \mathrm{C}$ resulted in a total loss of the volatile monoterpenes. Consequently, monoterpenes, like water, would not be represented in the quantity of dry, or organic matter, in either the forage or the residue and therefore, would not enter into the calculation of IVOMD. They would, however, still be present in the fresh tissues used for analysis and could influence in vitro digestion if they were active and did not evaporate from the tubes (Welch and Pederson 1981, Hobbs et al. 1986).
Unlike the monoterpenes, the nonvolatile crude terpenoids remain in oven-dried materials. Consequently, the nonvolatile compounds would be represented in the dry forage, or organic matter placed in fermentation tubes. Since they possess a variety of biological activities (Kelsey et al. 1985, Personius et al. 1987), they may not be digested or may actively inhibit the rumen microorganisms. Some of these compounds are also resistant to the hot water washes employed during the filtration of the undigested forage residue (Kelsey et al. 1982). Therefore, any nonvolatile crude terpenoids contained in the undigested forage residue after ovendrying would be subtracted from the quantity of dry forage or organic matter placed in fermentation tubes. This should lower the IVOMD of whole sagebrush compared to that with crude terpenoids extracted (Van Soest 1967, Kelsey et al. 1982).

If the observed variations in IVOMD of whole sagebrush were caused by seasonal nutrient fluctuations, it follows that trends in IVOMD of whole and terpenoid-extracted sagebrush would be similar, but this was not the case (Table 1). The terpenoidextracted sagebrush values characterize the influence that concentrated nutrient fractions have on increasing digestibility.

The biological activities of the sesquiterpene lactones found in basin big sagebrush and black sagebrush are consistent with their relative IVOMD. The black sagebrush samples contained cumambrins $A$ and $B$ (Personius et al. 1987), whose structures have an $\alpha$-methylene- $\Upsilon$-lactone functional group that is usually associated with biological activity (Dupuis et al. 1980, Hall et al. 1980a, 1980b, Spring et al. 1982, Picman and Picman 1984). The cumambrins cause allergenic contact dermatitis in some humans (Mitchell and Dupuis 1971). Both are phytotoxic (McCahon et al. 1973, Amo and Anaya 1978) and weakly antifungal (Picman 1984). Cumambrin B and its derivatives strongly inhibited the growth of some bacteria and weakly inhibited others (Picman and Towers 1983). Basin big sagebrush contained matricarin, deacetlymatricarin, and deacetoxymatricarin (Personius et al. 1987). Their structures suggest limited activity, because they have the less reactive $\alpha$-methylene- $\Upsilon$-lactone and a substituted $\alpha, \beta$-cyclopentenone (Lee et al. 1977). Experimental data confirm this (Mitchell and Dupuis 1971, McCahon et al. 1973, Lee et al. 1977, Picman and Towers 1983, Picman 1984). Based on these observations black sagebrush would be expected to inhibit digestion to a greater extent than basin big sagebrush. Of the 4 sagebrush taxa, black sagebrush had the greatest concentration of nonvolatile crude terpenoids and sesquiterpene lactones (Personius et al. 1987).

Most likley when animals browse sagebrush the highly volatile and some of the volatile compounds are lost with minimal influence on digestion (Cluff et al. 1982, White et al. 1982). Nonvolatile constituents have fewer routes of escape, and therefore, seem more likely to influence digestion if active. They could be absorbed with or without being digested, to be metabolized or excreted in the urine. Undigested and unabsorbed materials are eliminated in the feces. The digestive fate of sesquiterpene lactones is largely unknown. Metabolites of the toxic hymenoxon from bitterweed (Hymenoxys odorata DC.) have been isolated from the urine of sheep, but in minor quantities (Terry et al. 1983). $\alpha$-methylene- $\Upsilon$ lactones, as in the cumambrins, can bind easily, and nonreversibly, to free-SH groups in amino acids and protein (Rodriguez et al. 1976, Lee et al. 1977, Dupuis et al. 1980, Spring and Hager 1982). Binding with enzymes can destroy enzyme activity (Hall et al. $1980 \mathrm{a}, 1980 \mathrm{~b})$, resulting in reduced digestion.

Hobbs et al. (1986) reported that the volatile compounds in big sagebrush inhibit the digestion of grass cell walls. They contend that mule deer prefer sagebrush taxa that have no inhibitory substances and have therefore demonstrated a nutritional basis for divergence in herbivore preference for big sagebrush. We believe that inhibition of digestion is too slow and complex a mechanism to adequately explain the selection and preference on small cafeteria areas where there is a mixture of sagebrush species (Sheehy and Winward 1981, Welch et al. 1981, Personius et al. 1987). In order 
for digestion inhibition to work the animals must eat some of the inhibitory plants, with a lag period before the inhibition occurs and the animals respond. Consequently, during the lag period an animal could continue to eat the less preferred plant with inhibitory substances. The more eaten the faster the response. If every animal had to eat some of the inhibitory plant, then over time these plants should show substantial browsing, which they do not (Sheehy and Winward 1981, Welch et al. 1981, Personius et al. 1987). If the animals rapidly browsed 3 different species during the lag period, it would be difficult to associate inhibition with a particular plant or taxa. It is more likely that, in preference selection, the animals are responding to chemical stimuli that adversely affect their sensory organs. The biological activity of a compound is the consequence of a particular structure, or functional group(s), that can cause a variety of responses in different biological systems. Compounds that stimulate sensory organs are likely to also influence digestion. Sensory responses by mule deer to sagebrush chemicals would be a simple and rapid mechanism for sorting the taxa. Inhibition of fiber digestion is probably a quantitative regulator, rather than a qualitative regulator of sagebrush ingestion.

Disregarding the possible effect that sagebrush chemicals have on the digestion of other forages such as grass cell walls, there appears no nutritional basis for mule deer selection of big sagebrush. When given a choice of the 3 subspecies, they select mountain big sagebrush over basin big sagebrush (Sheehy and Winward 1981, Welch et al. 1981, Personius et al. 1987), although the latter maintains a higher crude protein level (Welch and McArthur $1979 \mathrm{~b})$ and is more digestible (Welch and Pederson 1981).

This investigation concluded that crude terpenoids contained in the folige of the 4 sagebrush taxa studied did inhibit the IVOMD of each taxon. Although digestibility is only 1 aspect to a taxon's merit as a forage source, it is of interest, particularly in plant materials programs as it relates to the possible influences of secondary metabolites (Welch and Pederson 1981). When considered with relationships of crude terpenoids to animal preference for the same 4 taxa (Personius et al. 1987) our findings should provide resource managers information for determining management opportunities.

\section{Literature Cited}

Amo, S.D., and A.L. Anaya. 1978. Effect of some sesquiterpenic lactones on the growth of certain secondary tropical species. J. Chem. Ecol. 4:305-313.

Beetle, A.A.1960. A study of sagebrush, the section Tridentatae of Artemisia. Univ. Wyoming Agr. Exp. Sta. Bull. 368.

Beetle, A.A., and A. Young. 1965. A third subspecies in the Artemisia tridentata complex. Rhodora 67:405-406.

Carpenter, L.H., O.C. Wallmo, and R.B. Gill. 1979. Forage diversity and dietary selection by wintering mule deer. J. Range Manage. 32:226-229.

Cluff, L.K., B.L. Welch, J.C. Pederson, and J.D. Brotherson. 1982. Concentration of monoterpenoids in the rumen ingesta of wild mule deer. $J$. Range Manage. 35:192-194.

Cook, C.W., L.A. Stoddart, L.E. Harris. 1954. The nutritive value of winter range plants in the Great Basin. Utah Agr. Exp. Sta. Bull. 372.

Dupuis, G., Benezra, G. Schlewer, and J. Stampf. 1980. Allergic contact dermatitis to $\alpha$-methylene- $\Upsilon$-butyrolactones. Mol. Immunol. 17:10451051 .

Hall, I.H., C.O. Starnes, Jr., K.H. Lee, and T.G. Waddell. 1980a. Mode of action of sesquiterpene lactones as anti-inflammatory agents. J. Pharm. Sci. 69:537-543.

Hall, I.H., K.H. Lee, C.O. Starnes, O. Muraoka, Y. Sumida, and T.G. Waddell. 1980b. Antihyperlipidemic activity of sesquiterpene lactones and related compounds. J. Pharm. Sci. 69:294-297.

Hansen, R.M., and L.D. Reid. 1975. Diet overlap of deer, elk, and cattle in southern Colorado. J. Range Manage. 28:43-47.

Harris, L.E. 1970. Nutrition research techniques for domestic and wild animals. Vol. 1. L.E. Harris, Logan, Utah.

Hickman, 0.E. 1975. Seasonal trends in the nutritive content of important range forage species near Silver Lake, Oregon. USDA Forest Serv. Res. Pap. PNW-187.
Hobbs, N.T., B.L. Welch, and T.E. Remington. 1986. Effects of big sagebrush on in vitro digestion of grass cell wall, p. 186-189. In: E.D. McArthur and B.L. Welch, compilers, Proc.-Symposium on the Biology of Artemisia and Chrysothamnus. USDA Forest Serv. Gen. Tech. rep. INT-200, Ogden, Utah.

Houston, D.B. 1982. The northern Yellowstone elk. Macmillan Publishers, New York.

Kelsey, R.G. 1986. Foliage biomass and crude terpenoid productivity of big sagebrush (Artemisia tridentata), p. 375-388 In: E.D. McArthur and B.L. Welch, compilers, Proc.-Symposium on the Biology of Artemisia and Chrysothamnus. USDA Forest Serv. Gen. Tech. Rep. INT-200, Ogden, Utah.

Kelsey, R.G., G.W. Reynolds, and E. Rodriguez. 1985. The chemistry of biologically active constituents secreted and stored in plant glandular trichomes, p. 187-241. In: E. Rodriguez, P.L. Healey, and I. Mehta (eds.), Biology and chemistry of plant trichomes. Plenum Press, New York.

Kelsey, R.G., and F. Shafizadeh. 1980. Glandular trichomes and sesquiterpene lactones of Artemisia nova (Asteraceac). Biochem. Syst. Ecol. 8:371-377.

Kelsey, R.G., J.R. Stevens, and F. Shafizadeh. 1982. The chemical constituents of sagebrush foliage and their isolation. J. Range Manage. 35:617-622.

Kelsey, R.G., W.E. Wright, F. Sneva, A. Winward, and C. Britton. 1983. The concentration and composition of big sagebrush essential oils from Oregon. Biochem. Syst. Ecol. 11:353-360.

Krysl, L.J., M.E. Hubbert, B.F. Sowell, G.E. Plumb, T.K. Jewett, M.A. Smith, and J.W. Wagzoner. 1984. Horses and cattle grazing in the Wyoming Red Desert, I. Food habits and dietary overlap. J. Range Manage. 37:72-76.

Lee, K.H., T. Ibuka, R.Y. Wu, and T.A. Geissman, 1977. Structureantimicrobial activity relationships among the sesquiterpene lactones and related compounds. Phytochemistry. 16:1177-1181.

McCahon, C.B., R.G. Kelsey, R.P. Sheridan, and F. Shafizadeh. 1973. Physiological effects of compounds extracted from sagebrush. Bull. Torrey Bot. Club. 100:23-28.

McNeal, A.F. 1984. Site characteristics and effect on elk and mule deer use of the Gardiner winter range, Montana. M.S. Thesis. Montana State Univ., Bozeman.

Mitchell, J.C., and G. Dupuis. 1971. Allergic contact dermatitis from sesquiterpenoids of the Compositae family of plants. Brit. J. Derm. 84:139-150.

Mueggler, W.F., and W.L. Stewart. 1980. Grassland and shrubland habitat types of western Montana. USDA Forest Serv. Gen. Tech. Rep. INT-66.

Nagy, J.G. 1979. Wildlife nutrition and the sagebrush ecosystem. In: G.F. Gifford, F.E. Busby, and J.P. Shaw (eds.), The sagebrush ecosystem: A symposium. Utah State Univ., Coll. Natur. Resour., Logan.

Peek, J.M., R.A. Riggs, and J.L. Laver. 1979. Evaluation of fall burning on bighorn sheep winter range. J. Range Manage. 32:430-432.

Personius, T.L., C.L. Wambolt, J.R. Stephens, and R.G. Kelsey, 1987. Crude terpenoid influence on mule deer preference for sagebrush. $J$. Range Manage. 40:84-88.

Picman, A.K. 1984. Antifungal activity of sesquiterpene lactones. Biochem. Syst. Ecol. 12:13-18.

Picman, A.K., and J. Picman. 1984. Effect of selected pseudoguaianolides on survival of the flour beetle, Tribolium confusum. Biochem. Syst. Ecol. 12:89-93.

Picman, A.K., and G.H.N. Towers. 1983. Antibacterial activity of sesquiterpene lactones. Biochem. Syst. Ecol. 11:321-327.

Rodriguez, E., G.H.N. Towers, and J.C. Mitchell. 1976. Biological activities of sesquiterpene lactones. Phytochemistry. 15:1573-1580.

Sheehy, D.P., and A.H. Winward. 1981. Relative palatability of seven Artemisia taxa to mule deer and sheep. J. Range Manage. 34:397-399.

Snedecor, G.W., and W.G. Cochran. 1980. Statistical Methods, 7th Edition. The Iowa State University Press, Ames, Iowa.

Spring, 0., and A. Hagar. 1982. Inhibition of elongation growth by 2 sesquiterpene lactones isolated from Helianthus annuus L. Planta 156:433-440.

Spring, O.., J. Kupka. B. Maier, and A. Hager. 1982. Biological activities of sesquiterpene lactones from Helianthus annuus: Antimicrobial and cytotoxic properties; influence on dna, rna, and protein synthesis. Z. Naturforsch. 37c: $1087-1091$.

Striby, K.D. 1985. The in vitro digestibility and utilization of big sagebrush and black sagebrush. M.S. Thesis, Montana State Univ. Bozeman. 
Terry, M.K., H.G. Williams, H.L. Kim, L.O. Post, and E.M. Bailey, Jr. 1983. Ovine urinary metabolites of hymenoxon, a toxic sesquiterpene lactone isolated from Hymenoxys odorata DC. J. Agr. Food Chem. 31:1208-1210.

Tilley, J.M., and R.A. Terry. 1963. A two-stage technique for the in vitro digestion of forage crops. J. Brit. Grassland Soc. 18:104-111.

Urness, P.J. 1979. Wildlife habitat manipulation in sagebrush ecosystems, p. 169-178. In: G.F. Gifford, F.E. Busby, and J.P. Shaw (eds.), The sagebrush ecosystem: A symposium. Utah State Univ., Coll. Natur. Resour., Logan.

USDA. 1981. Average annual precipitation, Montana. Soil Conservation Service, Bozeman, Mont.

Van Soest, P.J. 1967. Development of a comprehensive system of feed analyses and its application to forages. J. Anim. Sci. 26:119-128.

Welch, B.L. 1983. Big sagebrush: Nutrition, selection, and controversey, p. 21-33. In: K.J. Johnson (ed.), Proc. First Utah Shrub Ecology Workshop, Utah State Univ., Logan.

Welch, B.L., and E.D. McArthur. 1979a. Feasibility of improving big sagebrush (Artemisia tridentata) for use on mule deer winter ranges, $\mathrm{p}$. 451-457. In: J.R. Goodin, and D.K. Northington (eds.), Arid land plant resources. Texas Tech Univ., Lubbock.
Wejch, B.L., and E.D. McArthur. 1979b. Variation in winter levels of crude protein among Artemisia tridentata subspecies grown in a uniform garden. J. Range Manage. 32:467-469.

Welch, B.L., and E.D. McArthur. 1981. Variation of monoterpenoid content among subspecies and accessions of Artemisia tridentata uniform garden. J. Range Manage. 34:380-384.

Welch, B.L., E.D. McArthur, and J.N. Davis. 1981. Differential preference of wintering mule deer for accessions of big sagebrush and for black sagebrush. J. Range Manage. 34:409-411.

Welch, B.L., and J.C. Pederson. 1981. In vitro digestibility among accessions of big sagebrush by wild mule deer and its relationship to monoterpenoid content. J. Range Manage. 34:497-500.

Welch, B.L., J.C. Pederson, and W.P. Clary. 1983. Ability of different rumen inocula to digest range forages. J. Wildl. Manage. 47:873-877.

White, S.M., B.L. Welch, and J.T. Flinders. 1982. Monoterpenoid content of pygmy rabbit stomach ingesta. J. Range Manage. 35:107-109.

WIllms, W., A. McLean, R. Tucker, and R. Ritcey. 1979. Interactions between mule deer and cattle on big sagebrush range in British Columbia. J. Range Manage. 32:299-304.

\title{
Range Research: Basic Problems and Techniques
}

\author{
editors: C. Wayne Cook and James Stubbendieck
}

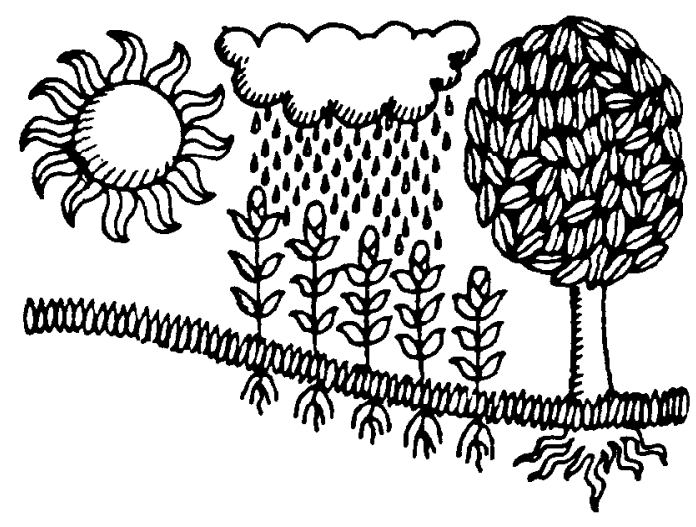

RANGE RESEARCH: BASIC PROBLEMS AND TECHNIQUES, a major revision of an earlier publication of the National Academy of Science, presents steps in research planning, evaluation of results, and methods and procedures in range research, including sampling techniques and experimental design. Chapter titles include: The Range Research Problem, Assessment of Habitat Factors, Methods of Studying Vegetation, Studies of Root Habits and Development, Methods of Measuring Herbage and Browse Utilization, Livestock Selection and Management in Range Research, Methods for Studying Rangeland Hydrology, Economic Research in Range Management, Sampling Methods with Special Reference to Range Management, Experimental Design, and Problems Involved in the Application of Research Techniques in Range Management. The book is designed to serve as a reference guide for range research methodology and as a textbook for advanced students who anticipate careers in this increasingly important field.

1986. 336 pages ISBN 09603692-3-6. \$28/hard.

Society for Range Management 2760 West Fifth Avenue, Denver, CO 80204 